\title{
Bernat Metge i Job: dos rebels amb causa però amb resolucions diferents
}

\author{
MiQuel Marco Artigas
}

El tema central del Llibre de Job i el del Llibre de Fortuna e Prudència de Bernat Metge - la raó humana enfront dels designis divins i l'existència de sofriment i de dolor, racionalment il-lògics- han estat tractats en el decurs de la història de la literatura universal. De sant Agustí a Metge, de fra Luis de León a Dostoieski, Kafka o Samuel Beckett, autors tan distants en el temps i en l'espai, han confluît en el tema que planteja el text bíblic convertint-lo en font d'inspiració literària. La temàtica del llibre sapiencial, a més a més, ja havia estat tractada per autors de l'antic Orient.'

El personatge central del relat, Job, és d'ascendència gentil, natural d'Us, ciutat que cal situar probablement a Edom; ${ }^{2}$ el propi Metge també ens parla de la gentilitat de Job en el diàleg que manté amb el rei Joan en el primer llibre de $L o$ Somni. Job representa el paradigma d'home atemporal i universal que es pregunta sobre el bé i el mal i la justícia divina. ${ }^{3}$ Metge es presenta en el Llibre de Fortuna e Prudència, igual que Job, sofrint, discutint i rebel-lant-se davant d'un problema que des del seu racionalisme no pot acceptar, ja que el considera injust. Fa, doncs, una assimilació personal amb el gentil-profeta ${ }^{4}$. Tanmateix, la resolució final del conflicte serà diferent en els protagonistes. Job continua sense entendre la qüiestió, però l'accepta com un misteri incomprensible per a

${ }^{1}$ Per a un millor i major coneixement dels precursors del Llibre de Job, vid., l'obra de L. Alonso Schökel i J.L. Sicre Díaz, Job, Comentario teológico y literario, Cristiandad, Nueva Biblia Española, Madrid, 1983, pp. 21-36.

2 «No se sabe con certeza dónde se encuentra la localidad de Hus, aunque sí se conoce que no es territorio israelita», Ibid, p. 97.

${ }_{3}^{3}$ «El autor ha querido dar carácter universal a su figura [Job] y obra. La experiencia de Job no es específicamente israelita, sino humana i universal», Ibid, p. 98.

${ }^{4}$ La doctora Júlia Butinyà proposa l'assimilació del caràcter bàsic de Job - rebel-lia i resignació- - amb el caràcter de Metge, qui desdoblaria en dues obres l'essència d'ambdues actituds. Correspondria al Llibre de Fortuna e Prudència el desenvolupament d'una actitud rebel i inconformista, mentre que en Lo Somni representaria una actitud molt més resignada en relació a la iniquitat i a la forma recta d'actuar de l'ésser humà: «Jo comens allà hon deig, car Job no fou jueu, ans fou ben gentil», dins Estudis de Llengua i Literatura Catalanes XXXI, Miscel-lània Germà Colón, 4, Publicacions de l'Abadia de Montserrat, Barcelona, 1995, p. 49. 
l'home, mentre que Metge ni comprèn el problema ni accepta la solució adoptada per Job, que és exponent de la filosofia tradicional medieval.

El punt de partida d'ambdós personatges davant l'omnipotència divina és idèntic. Déu és el Creador del món i tots els éssers estan sota els seus designis.

LJ: ¿Qui no ho sap, per tots aquests éssers, que és la mà de Jahvè que ha fet això, que de la seva mà és l'ànima de tot ésser vivent il'esperit en tota carn és el seu do?

LFP: -E doncs, pus ets d'opiniódix ella —que Déus creà el món, hajats per cert que cells qui són per Ell creat fan ço que Ell vol;

$$
\text { (vv. 744-747) }{ }^{6}
$$

La primera actitud que pren Job davant la fatalitat i la desgràcia és la resignació més absoluta. Té en compte que Déu atorga els béns terrenals i seva és la potestat de concedir-los o treure'ls segons els seus judicis. L'home els ha rebut de Déu. No obstant, aquesta actitud de submissió $\mathrm{i}$ acceptació variarà aviat en el relat i donarà pas a l'home rebel que proclama la seva innocència $i$ denuncia la injustícia que rep.

LJ: «Vaig sortir nu del ventre de la meva mare*

i nu hi tornaré.

Jahvè havia donat, Jahvè ha tornat a prendre;

que el nom de Jahvè sigui beneît.

* (la terra mare, a la qual tornen els homes quan moren, és assimilada al si matern)

LJ: Vam acceptar el bé com un do de Déu, i el mal, no l'acceptaríem?

$$
(2 ; 10)
$$

Aquesta inicial actitud resignada de Job no té comparació amb l'actitud de Metge, qui en tot moment es rebel-la davant el plantejament il-lògic que li proposa la mutable Fortuna. Aquesta li recorda que res no tenia en néixer i que tot allò que ha aconseguit ha estat perquè Fortuna ha volgut donar-li-ho.

LFP: No us recorda, segons que vei, que quan en aquest món vingués

${ }^{5}$ Les cites textuals del Llibre de Job pertanyen a l'edició de La Bíblia de Montserrat, versió dels textos originals i notes de Ramir Augé, Casal i Vall, Andorra, 1989.

- Les cites textuals del Llibre de Fortuna e Prudència procedeixen de l'edició de Marçal Olivar, Obres menors de Bernat Metge i Anselm Turmeda, Barcino, Els Nostres Classics, 10, Barcelona, 1927. 
res no hic portàs, e puis hagués menjar e beure e vestir; e de res no podets dir que per mi no ho hajats haüt. (vv. 546-551)

Davant d'aquesta afirmació Metge li replica:

LFP: - Na vella vil, no veurets vósdix ieu, que d'ara avant vos am; car més me plau morir de fam que si us havia a comportar.

(vv. 622-625)

Aviat deixa Job l'actitud submisa i resignada davant les desgràcies i adopta una postura molt més inconformista enfront de la conducta de Déu. Àdhuc desitjaria la mort com a alliberament dels seus mals. El seu plany amarg és una imprecació a la mort. Viure en dolor no té cap raó de ésser.

LJ: Que mori el dia que em va veure néixer, la nit que va dir: «Heus aquí un mascle! ¿Per què no vaig morir en el si matern, no vaig sortir del ventre, i expirar?

¿Per què havia d'haver-hi dos genolls per a acollir-me i dos pits per a alletar-me?

Aquesta nova postura de Job, més semblant al tarannà de Bernat Metge, concorda amb els següents versos:

LFP: Maleït sia cell qui primer de terra em llevà quant fui nat; maleït sia el vilà orat qui em batejà, com no em matà; maleït sia qui m'enconà, com no m'hi mesclà realgar

$$
\text { (vv. 530-535) }
$$

Ambdues obres presenten una semblant coincidència quan tracten del sofriment humà sense raó aparent i s'introdueixen en la temàtica del mal i del comportament de l'home, actitud d'ambdós protagonistes que es manifesta de forma coincident i reiterativa.

LJ: Jo mateix, quan hi penso, m'esfereeixo, i la meva carn és presa d'escruiximent: ¿per què han de viure el impius, fan anys, creixen i tot en puixança? [...]

Acaben els seus dies en el benestar i baixen de pressa al país del morts. 
LFP: Que, en ma fe quaix heretge en torn e los malvats seen egual dels prínceps e dels grans senyors, Ells han riqueses e honors; e, puis, que els pobles los adoren; e jamés no han mal ni ploren, ne saben què és adversitat,

(vv. 806-813)

LJ: Passen la nit nus, sense vestit i sense abrigall contra el fred. [...]

Circulen nus, sense vestit, i, afamats, s'enduen les garbes.

$(24 ; 7-10)$

LJ: ¿Quina seria, si no, la part que Déu fa des de dalt, l'herència que Saddai assigna des de les altures? ¿No és l'infortuni per a l'injust, la desgràcia per a la gent malèfica?

LFP: «Doncs - direts vós-, mal ordonat

és lo món, com així és partit.

Car molt aul hom vei ben vestit, ez ha diners, e ço que vol; e molt bon hom s'escalfa al sol per tal com no ha què s'abric.»(vv. 904-909)

LJ: I ara es riuen de mi uns que són més joves que jo, els pares dels quals hauria desdenyat d'admetre entre el gossos del meu ramat.

$[\ldots]$

I, ara, sóc la seva cançó burlesca, $m$ 'he convertit per a ells en una sàtira.

Corpresos d'horror, es mantenen a distància; davant meu no s'estan d'escopir.

LFP: grans mestres eren mos amics, mas ara em giten grans pessics, can me veen jaure al baix e gitant-me cascú son llaix bascant e cridant temps passat; e dien: «Veus qui ha gastat per sa gran colpa ço del seu, 
Job no entén els motius de la seva dissort i desitja saber quins són; per això prega Déu perquè li mostri el motiu pel qual un home recte i complidor de la seva doctrina - "els meus peu s'han atingut al seu pas,/ he seguit el seu camí sense desviar-me./ No m'he apartat mai del seu precepte,/ he guardat dins el pit les seves paraules» (23:11-12) - es troba en una situació tan injusta $\mathrm{i}$ tan incomprensible. Job pren com a referència la teoria de la retribució expressada en Els Salms, segons la qual Déu ha de guardonar en aquesta vida els bons i punir els inics.

LJ: Com són de grans la meva falta i el meu crim?

Feu-me saber quin ha estat el meu pecat!

[...]

Vull dir a Déu: «No em condemneu,

digueu-me per què em feu la guerra!

$$
(13 ; 23 \text { i } 10 ; 2)
$$

Metge es queixarà a Fortuna -sotmesa a les ordres del Creador- $;^{7}$ i per tant cal entendre-la com una queixa indirecta al propi Déu pel que fa a les seves particulars desgràcies que tampoc comprèn.

LFP: Digats, dona, ¿de què us tinc tort?

Digats, (mala mort vos hic lleu!),

¿fiu-vos jamés causa ten greu

que tal pena en deja portar?

$$
\text { (vv. 538-541) }
$$

I davant la manca d'una explicació raonable sobre l'injust mal que pateixen, ambdós resolen culpar Déu dels seus infortunis. La queixa de Metge és més velada ja que inculpa Fortuna de la seva adversitat, subordinada de la Providència: «-E doncs, pus ets d'opinió-/ dix ella— que Déus creà el món,/ hajats per cert que cells qui són/ per Ell creats fan ço que Ell vol;/ e no poden contra son vol/ fer, ne contra ço que Ell permet./ E doncs, si Fortuna us promet/ mal o bé, ¿com la podets creure?/ Semblant m'és que assats puixats veure/ que no ha poder absolut». (vv. 744-753).

«-Senyora, mon cor és pus trist,/ab menys esper que mai no fo;/ car ab lluent provació/ m'havets clarament demostrat/ que ço que per Déu és creat/ no pot res fer sens son voler,/ ho Ell permatent». (vv. 760-766).

LJ: Déu m'ha llençat al fang, m'he tornat igual que pols i cendra.

Us demano auxili, i no m'escolteu,

7 Adversa o favorable, la Fortuna és un instrument de la Providència divina. Boeci en la seva obra De Consolatione Philosophiae diu: «sic ergo, inquit Philosophia, omnis fortuna, sive haec prospera fuerit, sive adversa, ut pote quae a Deo providente oritur, ad ipsum Deum refertur, ut sit bona, nec nisi abutentium vitio mala: sic probos prospera remunerare, adversa exercere; improbos vero adversa punire, prospera emendare debet». (Lb. IV, pr. VII, argumentum) A. M. Sev. Boetii, De Consolatione Philosophiae, Patrologiae latinae, edició de J. P. Migne, Tomus LXIII, París, 1882, p. 823. 
ja no voleu fer cas de mi;

us heu tornat cruel per a mi,

m'ataqueu amb tot el vigor de la vostra mà:

perquè sé que em voleu fer habitar en la mort,

en la casa on s'han de reunir tants com viuen.

Però, ¿que no estira la mà el qui s'ofega,

o no crida auxili en el seu infortuni?

Perquè jo esperava el bé, i ha vingut el mal; comptava amb la llum, $i$ ha vingut el foscant.

$(30 ; 19-20-21-23-24-26)$

\section{LFP: «Partit-vos corrent denant mi}

e d'ací avant no.m parlets-.

[...]

-Na vella vil, no veurets vós-

dix ieu, (que d'ara avant vos am;

car més me plau morir de fam

que si us havia a comportar.

Car vós no us poríets estar

de tolre'm quant m'haguéssets dat.

$$
\text { (vv. 600-601; 622-627) }
$$

Job es nega a acceptar la postura tradicional que en diverses ocasions defensen els seus amics, els savis àrabs ${ }^{8}$, i que consisteix en la necessitat d'haver

${ }^{8}$ Elifaz, el temanita; Bildad, el suhita i Sofar, el naamatita, els tres amics que discuteixen amb Job la seva situació problemàtica, representen la saviesa tradicional i clàssica que defensa l'existència d'un Déu just i bo, que no castiga els innocents. Per tant, l'home és responsable del mal que pateix. Job pateix perquè ha pecat.

Elifaz: Pensa-hi, au: quin és l'innocent que s'ha perdut?

I on s'és vist que els justos siguin exterminats?

Tal com ho vist: els qui llauren la misèria

i sembren la sofrença, les cullen.

Bildad: Mira, Déu no rebutja pas l'home íntegre,

ni s'arrapa a la mà dels qui fan el mal.

$(8 ; 20)$

Sofar: Perquè és Ell qui coneix la gent perduda i veu la iniquitat i l'observa.

Job no pot, sota cap concepte, acceptar els plantejaments dels seus amics perquè són falsos. Acceptar-los significaria reconèixer que no és innocent. Job adopta en el decurs de tot el llibre sapiencial una tenaç defensa de la seva condició d'home innocent.

Job: si sóc just, la meva boca em condemna;

si sóc innocent, Ell em fa un pervers.

Sóc innocent, tant se me'n dóna de la vida, me'n ric de l'existència, tot és u!

[...] 
comès pecat per a justificar el càstig rebut. La teoria dels seus amics és la retribució: Job sofreix, llavors és culpable.

LJ: Pensa-hi, au: quin és l'innocent que s'ha perdut?

I on s'és vist que els justos siguin exterminats?

Tal com ho he vist: els qui llauren la misèria i sembren la sofrença, les cullen.

LJ: ¿És a causa de la teva pietat que et castiga

i que entra en judici amb tu?

¿No és per les teves múltiples maldats, per les teves culpes sense fi?

$$
(22 ; 4-5)
$$

En semblants termes s'expressa Metge en el seu poema narratiu i, també, posa en boca dels seus amics la mateixa reflexió que fan els interlocutors de Job: «l'home que pateix ha de cercar el motiu del seu dolor en el seu comportament malvat».

LFP: e dien; «Veus qui ha gastat per sa gran colpa ço del seu»,

I sabeu prou que jo no sóc culpable, que no he comès cap acte de perfídia.

$(9 ; 21$ i $10 ; 7)$

La insistència en les mateixes propostes per part dels amics de Job obligarà a aquest a rebutjarlos com a interlocutors i a requerir la presència de Deú com a única via de resolució i explicació al seu problema. Job no solament demana trobar Déu, sinó poder parlar i discutir amb Ell.

Job: que vosaltres no sou més que uns xarlatans, uns metges de fantasia sou tots!

¿Us penseu defensar Déu amb un llenguatge injust, i la seva causa, proferint mentides?

Job: Inicieu vós el debat, i jo respondré;

o deixeu que jo parli, i vós repliqueu-me!

Com són de grans la meva falta i el meu crim?

Feu-me saber quin ha estat el meu pecat!

¿Per què amagueu la vostra cara

i em considereu enemic vostre?

Solament el diàleg directe amb Déu farà canviar a Job la seva actitud, reconeixent el seu error i acceptant la limitació de l'intel-lecte per a jutjar els misteris de la creació que únicament Déu comprèn.

Job: Ni que em mati, jo seguiré esperant,

Sí, defensaré davant d'Ell la meva conducta.

I això sol ja és un prou per a justificar-me,

que un profa no gosa comparèixer davant d'Ell.

$(13 ; 15-16)$ 


\section{e sap bé Nostre Senyor Déu que d'açò vós n'havets lo tort.}

(vv. 448-451)

Posicions que representen una de les tendències més tradicionals del catolicisme de l'Edat Mitjana: la dualitat antitètica entre el bé i el mal que comporta premi o càstig respectivament, i la necessitat d'haver obrat amb malignitat per justificar el dolor i el sofriment rebuts.

Davant d'aquesta mentalitat, reflex d'unes religions antigues, es rebel-laran ambdós protagonistes en les seves obres i rebutjaran, en primer lloc, acceptar aquest principi.

A partir d'aquest punt culminant de la narratio, el llibre sapiencial plantejarà tota una sèrie de disquisicions i reflexions destinades a convèncer el pacient Job de la seva proposta errònia i fer-lo conscient de la seva ignorància.

Déu és just i no fa mal, no permet la injustícia i acaba aplicant el càstig als malvats. L'home, per la seva part, no pot jutjar la raó divina, ja que no ha adquirit el coneixement necessari per fer-ho. Solament la saviesa divina és inescrutable i l'home desconeix els límits dels saber de Déu; per tant, ha de confiar, com a única via possible, total i absolutament en la misericòrdia de Déu.

El llibre sapiencial deixa clar que el sofriment i el dolor són advertiments per a la conversió.

LJ: Déu rebutja el de cor obstinat i no deixa viure l'impiu, però concedeix als afligits el que reclamen, no priva l'humil dels seus drets.

I, si hi hagué uns reis al tron, que havia fet seure en l'esplendor, i s'ensuperbiren, van ser, doncs, lligats amb cadenes, van ser presos amb les cordes de l'aflicció.

Els retragué aleshores el que havien fet, la falta d'haver-se enorgullit; obrí la seva orella a la reprimenda i ordenà que es convertissin de fer el mal. Si escolten i serveixen Déu, acaben els seus dies en el benestar; però, si no escolten, passen al país dels morts, expiren perquè no tenen la ciència.

[...]

Mira de no donar-te al mal preferint la injustícia a la sofrença!

(36; 5-6-7-8-9-10-11-12-21)

Aquestes mateixes argumentacions apareixen en el poema de Metge i són defensades per Prudència. 
LFP: lo primer és, car los malvats del mal que fan són castigats; e lo segon, que s'espordeixen tots cells que en fer mal s'atreveixen quan vezen que als mals no pren bé.

$$
\text { (vv. 1019-1023) }
$$

LFP: - Molt amat fill, vós los direts a tots cells qui hic volran dubtar, que Déu l'ha volguda crear per exercitar o punir, remunerar o corregir los bons e els mals, segons llurs mèrits: los mals punir per llur demèrits e els hòmens bons remunerar e els hòmens justs exercitar perquè de si no presumesquen e perquè no s'atrevesquen a mal corregir los injusts.

La intervenció de Déu solucionarà els dubtes del gentil Job, qui reconeixerà l'omnipresència divina i acceptarà tot el que representa la Creació, àdhuc el sofriment i el dolor, doncs són misteris que l'home no abasta a comprendre i que ha d'acceptar.

El problema greu de Job sobre la justícia divina queda sense solució, però accepta la superioritat de Déu, la saviesa del qual pot, en ocasions, adreçar-se cap a realitats incomprensibles per l'ésser humà -dolor, mort, sofriment-, i que, com deia abans, ha d'acceptar, ja que l'home no és ningú per demanar explicacions a Déu per les seves actuacions.

LJ: Reconec que ets superior i res no és massa alt per a tu; per això, he parlat sense intel-ligència de meravelles que em sobrepassen i no sabia. Et coneixia només pel que sentia dir, però ara t'han vist els meus ulls!

Per això, ho desaprovo i me'n penedeixo sobre la pols i la cendra.

La resignació i acceptació de Job no té continuïtat en Metge; és aquí on se separen les posicions d'ambdós personatges que, fins al moment, havin circulat paral-leles. Metge es desmarca i deixa d'identificar-se amb la figura del pacient gentil i no accepta les propostes que han convençut a Job, continuant en la seva actitud rebel i blasfema. Actitud meritòria i lloable, ja que el nostre autor és capaç d'enfrontar-se sol a la Bíblia i fer una interpretació personal del text. Els planteigs sobre la justificació del mal i del bé, la necessitat de fe en Déu i la 
insuficiència de la raó humana per entendre importants qüestions que pertoquen a la Providència, és a dir, plantejaments de clar signe escolàstic, que defensa a continuació Prudència:

LFP: Per què, tenits per espatxat que Déu és jutge sobirà, e tot quant és fet, ne serà, al seu voler és subjugat, lo qual és tan ben ordonat que no fretura de millor; e que tothom té gran error, qui es met en cor de mantenir que Déus acostum fer ne dir permetre, voler ni mirar res que hom puixa imaginar que sia fait ab desraisó.

Mas humanal opinió aquests grans juis no pot entendre. Per què, no us en vullats contendre, d'ací avant, ab hom vivent;

e, si us plats, crezets fermament que Déu, qui és bé sobirà, lo món e ço que format ha a bona fi ho volc crear.

E si volets considerar del mal la difinició, coneixerets que mai no fo mal en est món, sinó tot bé. La difinició us diré:

Mal és de bé privació.

Doncs, no hi cal gran provació, que el mal que hom fa sia res; car privació res no és, ne el mal que hom fa, per consegüent.

Per què he provat clarament que tostemps és bona Fortuna. (vv. 1074-1105)

no són acceptats per Bernat Metge, que respon amb un marcat to irònic $\mathrm{i}$ sorneguer propis dels seu enteniment:

LFP: - Senyora, mai persona alguna-

dix ieu - no ho creurà si lo hi dic.

Quant és de mi, bé us certific

que no hi faria qüestió.

Doncs, major declaració

soplei a vós que me'n donets-. 


\section{$[\ldots]$}

E semblà'm que ab falles de foc

m'hagués hom donat per la cara, car no em volgra partir encara

de la sua gran excel.lença.

Però, ans de la departença acompanyà'm fins a la mar, e féu-me en la barca pujar ab qu'eu era vingut aquí.

$$
\text { (vv. 1148-1155) }
$$

rebutjant, en conseqüència, qualsevol pacte amb Fortuna, deixant clar així la seva ètica antimaterialista i la consciència de no acceptar allò que no entén.

LFP: - Na vella pudent, embriaga, fets-me lo pijor que puscats. ¿Cuidats-vos, si bé em menaçats que per això reta la força? Despullada m'havets l'escorça; no hi resta sinó la rabassa.

Prec Déus que tal gràcia me faça que en breu vos veja dejús terra, e puis en tota vostra guerra, ne en vós, no daria un carlí. Partit-vos corrent denant mi e d'ací avant no em parlets. -

$$
\text { (vv. 590-601) }
$$

-Na vella vil, no veurets vósdix ieu-que d'ara avent vos am; car més me plau morir de fam que si us havia a comportar. Car vós no us poríets estar de tolre'm quant m'haguéssets dat. (vv. 622-627) 